Discussion papers of the

Max Planck Institute for

Research on Collective Goods

Bonn 2018/6

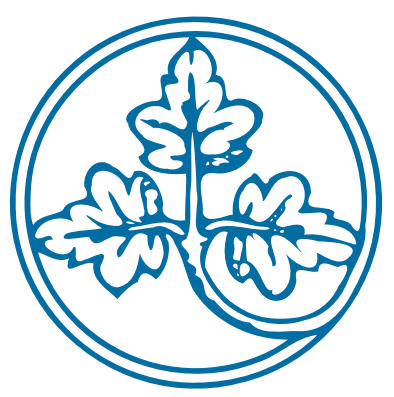

Valuation reports in the context of banking resolution: What are the challenges?

Martin F. Hellwig

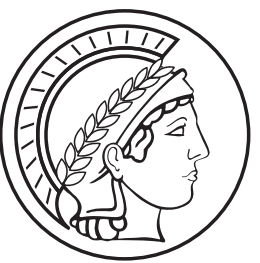




\title{
Valuation reports in the context of banking resolution: What are the challenges?
}

\author{
Martin F. Hellwig
}

July 2018

This material was originally published in a paper provided at the request of the Committee on Economic and Monetary Affairs of the European Parliament and commissioned by the Directorate General for Internal Policies of the Union and supervised by its Economic Governance Support Unit (EGOV). The opinions expressed in this document are the sole responsibility of the author and do not necessarily represent the official position of the European Parliament. The original paper is available on the European Parliament's webpage http://www.europarl.europa.eu/RegData/etudes/IDAN/2018/624417/IPOL_IDA(2018)624417_EN.pdf. (C) European Union 2016. Copyright remains with the European Union at all times. 
IN-DEPTH ANALYSIS

Requested by the ECON committee

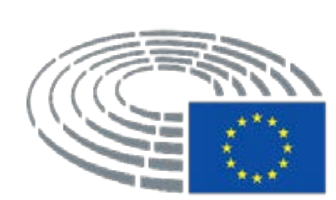

European Parliament

\section{Valuation reports in}

the context of

banking resolution:

What are the

challenges?

\section{Banking Union Scrutiny}

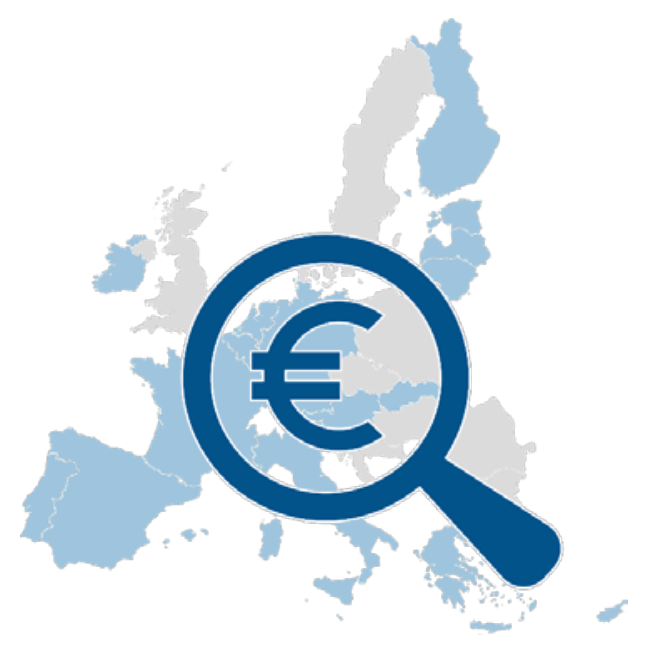

External author:

Martin F. Hellwig

Economic Governance Support Unit Directorate-General for Internal Policies of the Union PE 624.417 - June 2018 



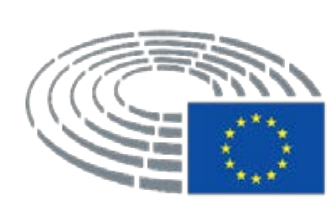

European Parliament

\section{Valuation reports in the \\ context of banking resolution: \\ What are the challenges?}

\section{Abstract}

The paper discusses the problem of valuation in bank resolution. In an overview over the most relevant principles of valuation theory, the paper notes the difficulties inherent in valuing risks and illiquidity in holding non-traded assets. Subsequently, the paper briefly reviews the resolution of Banco Popular Español, and then discusses the need for clarification of the no-investorworse-off principle, the relation between the price in a sale of business and the presumed outcome in an insolvency procedure, and the difficulties attached to assessing the value of an illiquid asset that is held. The paper concludes with a discussion of the need for time, for valuation and in resolution, warns against a moratorium on withdrawals and payouts, and argues that time pressures would be much reduced if funding in resolution was provided for. 
IPOL | Economic Governance Support Unit

This document was requested by the European Parliament's Committee on Economic and Monetary Affairs.

\section{AUTHORS}

Martin F. HELLWIG

\section{RESPONSIBLE ADMINISTRATOR}

Marcel MAGNUS

\section{LINGUISTIC VERSIONS}

Original: EN

\section{ABOUT THE EDITOR}

The Economic Governance Support Unit provides in-house and external expertise to support EP committees and other parliamentary bodies in shaping legislation and exercising democratic scrutiny over EU internal policies.

To contact Economic Governance Support Unit or to subscribe to its newsletter please write to: Economic Governance Support Unit

European Parliament

B-1047 Brussels

E-mail: egov@ep.europa.eu

Manuscript completed in June 2018

(c) European Union, 2018

Other studies are available at:

http://www.europarl.europa.eu/supporting-analyses

\section{DISCLAIMER}

The opinions expressed in this document are the sole responsibility of the author and do not necessarily represent the official position of the European Parliament.

Reproduction and translation for non-commercial purposes are authorised, provided the source is acknowledged and the publisher is given prior notice and sent a copy. 


\section{CONTENTS}

$\begin{array}{ll}\text { EXECUTIVE SUMMARY } & \mathbf{4}\end{array}$

1. INTRODUCTION

2. VALUATION BASICS

2.1 The Counterfactual Nature of Valuations 7

2.2 Principles of Asset Pricing 8

$\begin{array}{lll}2.3 & \text { The Valuation of Non-Traded Assets } & 10\end{array}$

2.4 Assessing Asset Return Distributions 11

$\begin{array}{llr}2.5 & \text { Interim Summary } & 13\end{array}$

3. VALUATION IN RESOLUTION 14

3.1 The Resolution of Banco Popular Español 14

3.2 The No-Investor-Worse-Off Principle 14

3.3 Valuations 2 and 3 and the Sale-of-Business Tool 16

3.4 Valuation 2, Economic Value and Hold Value 17

3.5 The Need for More Time: Would a Moratorium on Withdrawals and Payouts be Useful? 18

3.6 The Need for More Time: The Problem of Funding 19

$\begin{array}{lr}\text { 4. CONCLUSIONS } & 21\end{array}$

5. REFERENCES $\quad 23$ 


\section{EXECUTIVE SUMMARY}

The greatest challenge for valuation in resolution and for the resolution procedure itself is to establish credibility and legitimacy. "Value" is not something objectively given that one can easily measure. "Value" refers to a counterfactual, an exchange of an object for money that does not actually take place. The counterfactual nature of the concept creates no difficulties if similar objects actually are traded in markets. But even then one must be cautious about the possibility that the expression of a desire to trade may affect market prices.

For assets that are not traded in markets, the valuation of risks and of the costs of potential liquidity problems of the holder necessarily involve a certain element of arbitrariness. The same is true for the assessment of probability distributions of future returns on loans because default is a rare event and moreover, conditional probabilities of default are highly contingent on the situation of the overall economy and of relevant markets, such as real-estate markets.

In the BRRD and the SRM Regulation, the no-investor-worse-off principle plays a major role, but the principle raises several questions because the ex post outcome under an insolvency procedure is unknown and often unknowable. An application of this principle from an ex ante perspective, at the time when the resolution decision is taken raises questions about the treatment of risk and risk premia.

When the sale-of-business tool is applied, the sales price itself provides a good reference for Valuation 3 , at least if the bidding process was sufficiently competitive. An assessment of competitiveness of the bidding process should take account of the fact that a small number of bids received may reflect the poorness of the bank's assets and prospects rather than a lack of competition.

The concept of "economic value", as distinct from market value, is problematic if there is no feasible strategy attached to it. The judgment that prices are abnormally low, so that holding and managing them promises greater value may be a legitimate business judgment, but it presumes that this strategy of holding and managing them is actually feasible. If valuation is based on this strategy, an assessment of hold value ought to take account of risk and of illiquidity costs.

Any strategy of holding assets needs funding. The BRRD and the SRM Regulation are silent on the subject of funding in resolution. The lack of provisions for funding in resolution is a major reason why time pressure is so strong in the European Union, unlike the United States, where the FDIC can obtain interim funding by borrowing from the Treasury. To reduce the time pressure on valuation and resolution and to make holding assets a viable strategy, it would be desirable to amend the legislation to provide for funding in resolution.

In the case of BPE, due to the run on the bank, time pressure also affected the valuation by external valuers (Valuation 2). The proposal to allow for a moratorium on payouts would not solve the problem; it might however have disastrous side effects. Some time might by gained if the valuation process was initiated sooner, with appropriate safeguards against indiscretions that might themselves trigger a run.

Providing the valuation with more time may improve the information that is available, but it cannot eliminate the elements of subjectivity and arbitrariness inherent in the valuation of risks and of illiquidity of non-tradable assets. It also cannot eliminate the elements of subjectivity in the assessment of conditional probability distributions of future returns where reliable data are altogether missing. 


\section{INTRODUCTION}

In the aftermath of the financial crisis of 2007-2009, the European Union has introduced a legal framework for bank resolution as an alternative to a traditional insolvency procedure. The Lehman Brothers bankruptcy had shown that, even if the prevailing legal regime is debtor friendly and favours the continuation of operations of the insolvent company, letting a major financial institution go into bankruptcy can cause severe damage to the financial system. Bank resolution should provide a way to deal with the bank's problems without causing such damage.

Resolution affects the rights of banks' creditors. In contrast to traditional insolvency law, the legal norms concerning bank resolution prioritize the protection of the financial system over creditor protection. In particular, the bail-in tool provides for the possibility of imposing losses on creditors without going through an insolvency procedure.

Under the "no-creditor-worse-off" principle (Art. 73 (b) BRRD, Art. 15 Par. 1 (g), SRM Regulation), a bailin should not make any creditor worse off than an insolvency procedure would. However, the counterfactual of what an insolvency procedure would imply for creditors is difficult, perhaps even impossible, to ascertain.

Write-downs and conversions in a bail-in depend on the valuation of the bank's assets. If the assessed total value of assets falls short of the creditors' total claims, shareholder equity is written down. Debt is bailed in, by write-downs or conversions, in the inverse order of its standing in the hierarchy of claims.

The impact of a bail-in on creditors is obviously very sensitive to the results of the valuation. For the valuation, Articles 36 and 74 of the BRRD and Article 20 of the SRM Regulation stipulate a two-step procedure. The first valuation takes place when the resolution procedure is initiated, the second, when the resolution procedure is finished. The purpose of the first procedure is to provide a basis for the resolution authority's choice of actions, including a bail-in of creditors. The purpose of the second procedure is to compare the claims of shareholders and creditors under the initial bail-in to the payments they would have received in an insolvency procedure, providing for compensation if the latter claims turn out to be larger.

In cases where the urgency of resolution precludes a valuation by independent agents that complies with all conditions in the Directive and the Regulation, the resolution authority can proceed on the basis of a provisional valuation. This provisional valuation must be replaced by a definitive valuation that fulfils all the conditions in the Directive and Regulation as soon as possible.

These arrangements raise a number of questions. Some of these questions have been articulated in the discussion about the European Banking Authority's (EBA) regulatory technical standards (RTS). ${ }^{1}$ Some of them have arisen from the experience with the resolution of Banco Popular Español (BPE) in June 2017.

One set of questions concerns the relation between the two valuations and the relation between them and the valuations that preceded the authorities' assessment that a bank was failing or likely to fail. EBA observes that the three valuations occur in different circumstances and serve different purposes: Valuations before the initiation of resolution ("Valuation 1") provide information to market participants in the absence of any intervention. Valuations at the onset of resolution ("Valuation 2") provide an input into the resolution authority's decisions. Valuations after resolution ("Valuation 3") serve as a basis for implementing the no-investor-worse-off principle. To take account of these differences, EBA proposes

${ }^{1}$ EBA (2017) 
to use different approaches to the three kinds of valuations, standard accounting rules for Valuation 1, an assessment of "economic value" for Valuation 2, and a gone-concern assessment for Valuation 3.

The proposal has met with some criticism. In particular, the question was raised what the term "economic value" is supposed to mean and how it makes a difference relative to standard accounting rules.

The discussion touches upon the more encompassing question of what information is used and how new information should affect the valuations. This question concerns the transition from Valuation 1 to Valuation 2 as well as the transition from Valuation 2 to Valuation 3. In the transition from Valuation 1 to Valuation 2, the initiation of the resolution procedure itself is a new piece of information that is relevant for valuation. Moreover, one may suppose that the information that motivated the initiation of resolution was also not contained in previous valuations.

In the transition from Valuation 2 to Valuation 3, the question is how to deal with the information about, say, the salability of the business or of some of its assets that is generated while the resolution process is going on. On the one hand, the no-investor-worse-off principle refers to an ex post standard of comparison. In a standard insolvency procedure, payouts to creditors are only determined ex post, after the firm's assets have been liquidated and all expenses have been paid. Any information that the liquidation process itself generates is automatically taken into consideration. On the other hand, the bail-in actions for which the no-investor-worse-off principle provides a standard of comparison are taken at the time when the resolution procedure is initiated, subsequent information is not yet available, and there may be considerable uncertainty about the results of the resolution procedure.

However, the Directive and Regulation are silent on how to deal with this uncertainty. As a general principle, uncertainty affects valuations. For example, if one considers applying the no-investor-worseoff principle at the time when resolution begins, one must think about the implications of an insolvency procedure for investors in terms of random payouts at future moments in time whose realizations are not yet known. From the investors' perspective, the uncertainty matters for the valuation.

The issue of how to deal with uncertainty is implicit in the question of what discount rates to apply, which is considered in the discussion of EBA's proposed RTS. The issue is also implicit in the Directive's and Regulation's allowance for a buffer to protect resolution authorities against losses. However, it is not considered explicitly.

A final issue concerns the availability of the requisite information. This is not just a question about the available documentation and data. It is also a question of how to deal with the fact that the very actions taken by the resolution authority foreclose the alternatives that would be chosen in an insolvency procedure so that, for reasons of principle, the information required for Valuation 3 may be unavailable.

In the following, I will address these issues and the challenges they pose for valuation in the context of resolution. Before going there, however, I will address some basic conceptual issues. 


\section{VALUATION BASICS}

The concept of "value" involves an exercise in counterfactuals. The assessment of value therefore depends on which counterfactuals one considers and what assumptions one makes about them. Importantly, the assessment of value also depends on which course of action one considers. Which method of valuation is appropriate may therefore depend on the purpose for which the information contained in the valuation is used.

\subsection{The Counterfactual Nature of Valuations}

The statement "Object $x$ is worth y euros" refers to a potential exchange of the object against money. As a statement from the owner, it may indicate a willingness to sell the object for $y$ euros; as a statement from a potential buyer, it may indicate a willingness to buy it for y euros. Such statements from interested participants however involve an important element of subjectivity, perhaps also an attempt at manipulating the terms of an intended exchange.

The impact of subjectivity is reduced or even eliminated if the sentence is read as a statement about trading opportunities in a market. For example, if object $\mathrm{x}$ is a financial asset that is traded in an organized exchange, the statement might mean that the prevailing market price is $y$ euros. More generally, the "fair value" of object $x$ is $y$ euros, if an owner can reasonably expect to find a buyer at this price and a potential buyer can reasonably expect to find a seller at this price.

As a statement about fair value, the sentence "Object $x$ is worth $y$ euros" does not presume that the transaction in question actually takes place. However, unless the transaction actually takes place, there is no way of knowing whether it really is possible to trade the object for $y$ euros.

When trading happens in a frictionless organized market, without information asymmetries and without market power of participants, the counterfactual nature of valuation poses no serious problem. Apart from the fact that overnight news may cause tomorrow's price to be different from today's price, in such a market, today's price is a fairly precise predictor of the price at which the object will be traded in the near future.

When these conditions are not satisfied, however, the counterfactual nature of valuation can cause serious problems. If markets are not well organized, it may be difficult to find a trading partner in reasonable time.

Even worse, the very attempt to trade may cause the market price of the object to change. This phenomenon arises, in particular, from effects of asymmetric information and/or market power. Asymmetric information can give rise to the so-called "lemons" effect, whereby the very attempt of an owner to sell an object is interpreted as a signal that the object is of poor quality. ${ }^{2}$ Such information effects will cause the price of the object to fall as a consequence of the owner's trying to sell it. For example, in the context of a bank with a portfolio of non-performing loans, the very attempt to sell the portfolio may provide the market with a signal that default probabilities are even higher than anticipated causing potential buyers to require higher discounts.

Market power effects can occur when the trader in question is relatively large. An example would be a central bank trying to sell its gold stock in the open market. Another example would be a corporation

\footnotetext{
${ }^{2}$ See Akerlof (1970).
} 
issuing equity or selling assets to buy back its own junior debt. Such a recapitalization would lower default probabilities for junior debt, making the price of this debt go up. ${ }^{3}$

When such effects are present, fair-value accounting fails to give an accurate picture of the trading opportunities that are actually available. For example, the practice of using mark-to-market accounting for a firm's liabilities may give an accurate picture of investors' trading opportunities, but it does not give an accurate picture of the firm's trading opportunities. ${ }^{4}$ If the firm buys back debt, it causes the price of at least one class of debt to go up; if it issues new debt, it causes the price of at least one class of debt to go down.

In such situations, one can only obtain an accurate picture of the firm's trading opportunities if one considers the whole schedule relating market prices to desired trades. With market power effects, one would expect the price to become the more unfavourable the larger the desired trade is. With information effects, one might expect the market price to be less unfavourable if the desired trade is larger because in this case, the potential buyers' fears of an adverse selection in the choice of objects put up for sale might be smaller.

Importantly, if one wants the valuation to result in a single number, then in cases where information and monopoly effects are present, the number may have to be conditioned on desired trades in order to have any chance of being accurate.

\subsection{Principles of Asset Pricing}

Most valuation methods start with an assessment of the stream of future returns from the asset and then transform this stream into a "present value" by applying some form of discounting. Critical questions are how to deal with uncertainty about the future returns and how to discount them. To address these questions, one must go back to the principles of asset pricing theory.

In its simplest form, asset valuation by discounted present values of future returns can be understood as an application of the no-arbitrage principle or, equivalently, the law of one price. The law of one price asserts that any two units of the same homogeneous good must trade for the same price. The noarbitrage principle asserts that any two assets which have the same return streams must trade for the same price.

As an example, consider a loan that is free of default risk and promises to pay $R$ euros after each year for the next ten years, as well as returning the principal $X$ at that time. The same return stream could be generated by investing $R /\left(1+r_{1}\right)$ in a one-year safe debt instrument with interest rate $r_{1}, R /\left(1+r_{2}\right)$ in a two-year safe debt instrument with interest rate $r_{2}, \ldots$, and $(R+X) /\left(1+r_{10}\right)$ in a ten-year safe debt instrument with interest rate $r_{10}$, where for simplicity I have assumed that these debt instruments do not provide any returns in the interim, before they reach their maturities. The no-arbitrage principle implies that the value of the loan today must equal the sum of the amounts $R /\left(1+r_{1}\right), R /\left(1+r_{2}\right), \ldots$, $(R+X) /\left(1+r_{10}\right)$. This sum is the discounted present value of the return stream $R, R, \ldots . R+X$.

Underlying the calculation is the assumption that, in the market, there exist safe debt instruments with payouts at dates $1,2, \ldots, 10$. The discount rates $r_{1}, r_{2}, \ldots, r_{10}$ are the interest rates for these debt instruments that prevail in the market.

Can one use this kind of procedure if the returns on the loan are uncertain? Based on the work of Arrow (1954/1963) and Debreu (1959), the answer to this question is "yes" if the market system is what is called "complete". For simplicity, consider a loan with a maturity of one year and suppose that, with a probability $p$, the debtor pays the amount $R+X$ that was promised and, with a probability $(1-p)$, the

\footnotetext{
${ }^{3}$ See Admati et al. (2018) and the references given there.

${ }^{4}$ On this point, see Admati et al. $(2018,156$, n. 13).
} 
debtor cannot pay anything. Suppose that, in the market, there is another asset that pays 1 in the very event in which the loan pays $\mathrm{R}+\mathrm{X}$ and that pays 0 in the event where the loan pays nothing. Let $q$ be the market price of this instrument. Then, by the no-arbitrage principle, the value of the loan must be $q(R+X)$.

The market system is said to be complete if, for every date and every realization of the underlying uncertainty up to that date, there is a security that pays 1 euro at that date and realization of the underlying uncertainty and that pays nothing at any other date or other realization of the underlying uncertainty. In a complete market system, every asset is equivalent to a bundle of such Arrow-Debreu securities, and by the no-arbitrage principle, the value of every asset is unambiguously determined as the value of this equivalent bundle of Arrow-Debreu securities valued at Arrow-Debreu prices.

The concept of an Arrow-Debreu security is very abstract. However, the notion that every asset can be interpreted and priced as a bundle of such securities is fundamental to the modern theory of asset pricing. This notion is useful even if the market system is incomplete. For any participant and any asset position that this participant holds, one can ask at what system of Arrow-Debreu prices the participant would be happy with the position he holds if he could trade in a complete market system. If the asset position in fact results from a market equilibrium in a complete market system, the answer will be the same for all participants, so valuation of assets as bundles of Arrow-Debreu securities is unambiguous. ${ }^{5}$ If the asset position results from a market equilibrium in an incomplete market system, the answer will not be the same for all participants. In this case, the valuation of assets as bundles of Arrow-Debreu securities is ambiguous.

The condition that the market system be complete is restrictive but not quite as restrictive as it looks. Even if there are no Arrow-Debreu securities at all, the markets may behave, as if there was a complete system of such securities because the markets that do exist are in fact rich enough to enable the synthetic construction of Arrow-Debreu securities by suitable trading strategies. In particular, in an intertemporal setting, the theory of derivatives pricing that was initiated by Black and Scholes (1973) and by Merton (1973a) has shown that, even when there are just two securities in the market, a stock and a bond, dynamic trading strategies can be used to mimick any Arrow-Debreu security. ${ }^{6}$

In the above example of a loan that pays $(R+X)$ with probability $p$ and 0 with probability $(1-p)$, in the formula $q(R+X)$ for the loan's value, the price $q$ of the alternative asset takes the place of the discount factors $1 /\left(1+r_{1}\right), 1 /\left(1+r_{2}\right), \ldots, 1 /\left(1+r_{10}\right)$ in the preceding example. If $p$ were equal to one, i.e., if the default probability of the loan was zero, q must in fact be equal to the one-year discount factor $1 /\left(1+r_{1}\right)$ because in this case, the alternative asset and the loan are both equivalent to the one-year safe debt instrument. If $p$ is less than one, however, i.e. if the default probability on the loan is positive, the loan and the alternative asset to which it is equivalent are less valuable than the one-year safe debt instrument, and $q$ will be less than $1 /\left(1+r_{1}\right)$.

At this point, it is tempting to set $q=p /\left(1+r_{1}\right)$, i.e. to think about the Arrow-Debreu valuation as a combination of weighting by probabilities and discounting. This procedure is in fact correct if the participants are risk neutral, at least with respect to small changes in their asset positions. In this case, the loan's value would be $p(R+X) /\left(1+r_{1}\right)$, i.e. the expected value of the random return which takes values $R+X$ with probabilities $p$ and $1-p$, discounted back by one year.

However, if the participants are not risk neutral, the Arrow-Debreu prices cannot generally be obtained by combining probability weighting and discounting. In this case, risk preferences also play a role. If

\footnotetext{
${ }^{5}$ See Harrison and Kreps (1979). What they refer to as an equivalent martingale measure is in fact the system of Arrow-Debreu prices at which a participant is satisfied with the portfolio he holds. Their uniqueness result for equivalent martingale measures in a complete market system corresponds to the statement that, in such a system, valuation of assets as bundles of Arrow-Debreu securities is unambiguous.
}

${ }^{6}$ In addition to the cited papers, see Ross (1976) as well as Harrison and Kreps (1979). 
participants are risk averse, the value of an asset will typically be less than the sum of the discounted expected values of its random returns in different periods.

For suppose that, in the given example, the event where the loan pays $\mathrm{R}+\mathrm{X}$ is an event in which the overall economy is doing well and the event where the loan pays nothing is an event in which the overall economy is doing poorly. If the prices of Arrow-Debreu securities were proportional to probabilities, then from an ex ante perspective, risk-averse agents would like to buy Arrow-Debreu securities on the "bad" event, paying with Arrow-Debreu securities on the "good" event, up to the point where they have eliminated the return risk. However, since the economy is doing poorly in the "bad" event, elimination of the return risk for every one is not feasible. To make people will to accept the aggregate return risks that are inherent in the fate of the overall economy, Arrow-Debreu securities on the "bad" event must be relatively more expensive, and Arrow-Debreu securities on the "good" event must be relatively cheaper, than they would be if Arrow-Debreu prices were proportional to the probabilities of events. The equilibrium value of the bundle of Arrow-Debreu securities that is equivalent to the loan will therefore be smaller than $p(R+X) /\left(1+r_{1}\right)$, the expected value of the return, discounted back by one year. The difference must be understood as a risk premium.

The size of the risk premium depends on risk preferences in the economy, on the extent of aggregate risk in the economy, and on the correlation between the risk of the asset under consideration and the aggregate risk in the economy. In the preceding analysis, the argument implying that the risk premium is positive depended on the assumption that the event where the loan does well is the same as the event in which the economy does well. If the reverse were true, i.e. the event in which the loan does well is one in which the economy does poorly and vice versa, the risk premium would actually be negative because by buying the loan - or the Arrow-Debreu securities that mimick its returns - one would actually transfer resources from the event where the economy does well to the event where the economy does poorly, so at prices proportional to probabilities, there would be an excess demand for these positions.

Standard asset pricing formulae that are used in practice reflect these insights and provide workable simplifications of the general approach. For example, for an asset with a maturity of one period, ${ }^{7}$ the well-known Capital Asset Pricing Model (CAPM) of Lintner (1965) and Sharpe (1964) derives a formula for the risk premium, i.e. the difference between the discounted expected value of the asset's random return and its equilibrium price, in terms of the covariance between the asset's return and the return on the aggregate of all assets and a constant that is called the market price of risk,a parameter that reflects risk preferences and that is the same for all assets. Reference to the market price of risk eliminates the need to ascertain risk preferences and reduces the problem of asset valuation to one of determining expected values and risk characteristics of the assets random returns, the latter in relation to the relevant notion of aggregate risk in the system.

An important finding is that, once one takes account of uncertainty, there is no single discount rate that is appropriate for asset valuation. Rather, one must rely on the information about risk valuation that is inherent in the overall system of asset prices.

\subsection{The Valuation of Non-Traded Assets}

For many assets, reference to a market price makes no sense. Organized markets for these assets do not exist. If the markets exists, frictions and information effects may be so large that selling these assets is unattractive, and a strategy of holding them must be preferred.

The valuation of such assets relies on a notion of "hold value", which seems like a contradiction in terms. A statement like "Object $x$ is worth y euros" is problematic if there are no trades involving the exchange of object $x$ for $y$ euros.

\footnotetext{
${ }^{7}$ If maturities extend over multiple periods and there is trading in each period, additional considerations come in, such as: How is an asset's return over the next period correlated with potential changes in return opportunities for subsequent investments? See Merton (1973b).
} 
In the context of "hold value", the statement "Object $x$ is worth y euros" actually becomes "Object $x$ is similar to object $Q$, which is traded, and object $Q$ is worth y euros". One considers the return stream from holding object $x$ to maturity, looks for an object $Q$, which is traded, and applies the no-arbitrage principle. Once the equivalence of objects $x$ and $Q$ is assumed, one can proceed as in the case where the object $x$ is tradable.

There is, however, an inherent contradiction between, on the one hand, the assumption that two objects are equivalent and, on the other hand, the fact that one is tradable and the other one is not. If they really were equivalent, one would expect that either both are tradable or both are non-tradable. If the return streams are the same in all circumstances, the forces that preclude object $x$ from being traded should also preclude object $Q$ from being traded. Moreover, the difference in tradability itself is a factor that must be considered in valuation.

To understand the issues, go back to the above example of a loan that is free of default risk and promises to pay $R$ euros after each year for the next ten years, as well as returning the principal $X$ at that time. By the arguments given above, the hold value of this loan is equal to the sum of the amounts $R /\left(1+r_{1}\right), R /\left(1+r_{2}\right), \ldots,(R+X) /\left(1+r_{10}\right)$ that are needed to obtain the same return stream by investing in safe debt instruments with maturities $1,2, \ldots, 10$ when the corresponding interest rates are $r_{1}, r_{2}, \ldots, r_{10}$. Suppose that, e.g. because of information problems, a sale of the loan is not feasible, or at least not without a significant loss of value. If the loan and the bundle of safe debt instruments that are used for the valuation are equivalent, why can the bundle of safe debt instruments be traded without any concerns about information problems?

The argument might be that, for some reason or other, investors in the market are fully informed about the return prospects for the bundle of safe debt instruments, but do not know the return prospects of the loan. The owner, the resolution authority, and the valuer might know it, but they may be unable to communicate this information effectively to the market.

In this case, however, the postulated equivalence can only be taken for granted if tradability is economically irrelevant. This condition is satisfied, e.g. if the loan or the equivalent bundle of debt securities are held by a public authority with guaranteed funding from the government. It is typically not satisfied if the assets in question are held by a private institution that might run into funding problems during the holding period. For a private institution that is concerned about interim funding problems, the hold value of a non-tradable loan is lower than the hold value of a bundle of tradable debt securities with the same return pattern. The difference reflects the costs of potential interim funding problems and may be called an illiquidity premium. In any attempt to sell the loan, the illiquidity premium would come on top of the information and market power effects that I discussed above.

\subsection{Assessing Asset Return Distributions}

The discussion so far has focused on the valuation of the timing and riskiness of returns and on the issue of tradability of assets. In the process, the distribution of returns on the asset in question was taken as given and known. In practice, the assessment of this distribution is a major task.

For assets that are traded in frictionless competitive markets, the problem is moot because one can assume that the market itself (market investors) performs the operation. The no-arbitrage principle ensures that the pricing of different assets and the return expectations for different assets are mutually consistent.

For assets that are not traded, there are no market prices that provide reliable information about values. For such assets, the valuer himself must assess returns patterns and infer values. This operation can involve an important element of subjectivity.

Take another look at the case of a loan, where after one year, either the debtor pays $\mathrm{R}+\mathrm{X}$, or the debtor pays nothing at all. The question is how to assess the default probability 1-p. 
One answer to this question is that this assessment is entirely subjective, at least for loans to small and medium enterprises (SME). Each of these firms has unique characteristics, and, even if one abstracts from some characteristics to form classes, the classes are not large enough to provide statistically reliable estimates.

In the past, this view was prevalent among practitioners and was used to mark a major difference between banking and insurance because insurers can often rely on large populations so that they have statistically reliable estimates of accident probabilities, death probabilities, survival rates, and the like. In the 1990s, attitudes changed, and a belief in the possibility of obtaining statistically reliable estimates of default probabilities underlay both the Basel II agreement on capital requirements for credit risk and the development of credit default swaps as a device to provide insurance for credit risk.

The empirical record of banks' applying the internal-ratings-based approach raises some doubts about this belief. ${ }^{8}$ The doubt must be even greater if one takes account of the fact that, contrary to the typical model of credit risk, the underlying processes are not stationary but exhibit non-stationarities such as those that tend to be associated with the business cycle or with boom-and-bust phenomena in certain markets such as those for real estate of for ships. In these cases, at the point of resolution, one is interested in conditional default probabilities, given that the overall economy or the boom-and-bust markets are in bad shape, and the bank itself is in trouble.

The issue is illustrated by the fact that over the past decade, both banks and authorities were very slow to recognize the impact of bursting bubbles in real estate and shipping on the default probabilities of borrowers. The boom-and-bust nature of developments in these markets was not immediately understood. Poor loan performance was attributed to the recessions after 2008. The fact that cycles for long-lived assets may last much longer than the ordinary business cycle tends to be overlooked. ${ }^{9}$

In a case like that of Banco Popular Español (BPE), where real-estate and SME lending were major sources of losses, the problem assessing return prospects for loans was mitigated by the fact that the Spanish authorities had some experience with the matter, in the very crisis that affected BPE. Two aspects are of particular interest here. First, Sareb, the government asset management company that had taken over bad loans from Spanish banks in 2012 and 2013, needed to increase its provisions by another $€ 2$ billion in 2015, indicating that initial loss estimates had been too optimistic. Second, the experience of Sareb provided information about the marketability of collateral that had been seized from defaulting borrowers, for example, information on how the salability of real estate varied with its location. Such information on losses and collateral for comparable loans that had been hit by the same crisis is an important input into the valuation of a loan portfolio. ${ }^{10}$

The problem is akin to the problem of assessing infection risk and safety measures in an epidemic like the so-called Spanish flu in 1918, which itself was viral but was accompanied by bacterial infections of

\footnotetext{
${ }^{8}$ Behn, Haselmann, and Vig (2016) show that assessed probabilities of default tend to be smaller and actual probabilities of default larger when banks use the IRB approach to determined required capital than when they use the standard approach.

${ }^{9}$ Thus, in April 2013, the governments of Hamburg and Schleswig-Holstein and their Landesbank HSH Nordbank proposed to increase the government guarantee for HSH Nordbank by $€ 3$ billion and forecast that the shipping crisis would be over by the end of 2014. At the same time, forecasts had capacity in global shipping go up by $10 \%$ in 2013; the corresponding growth forecast for world trade was only 5\%, so excess capacity in shipping was still rising. The two governments and the bank's management considered this fact to be irrelevant - or found it convenient to do so. See Hellwig $(2013,2018)$.
}

${ }^{10}$ For more on these issues, see Hellwig (2017). 
the lungs. Once the epidemic was there, ex ante assessments of infection risks and causes were useless, so the statistical analysis had to be carried out from scratch. Then the problem of distinguishing the different causes of different diseases that all came together and all were linked to each other posed an additional challenge.

\subsection{Interim Summary}

The preceding analysis has shown that in many circumstances the "value" of an asset is not well defined. The problem is not just that the information required to assess "value" may not be available or that there are different methods for assessing "value". The problem is that the notion of "value" itself may be problematic.

The fundamental difficulty is that an assessment of value involves an exercise in counterfactuals, namely a fictitious exchange that does not actually take place. Most valuation procedures assess values of assets by considering other assets that are traded in markets and that have the same (or at least similar) distributions of return streams as the ones that one wants to value. For assets that are not tradable, such equivalent assets may not exist. In this case, one must also assess the value implications of the differences between the assets one wants to value and the "equivalent" traded assets, which are not really equivalent. The problem concerns the pricing of risks for which there is no information in market prices and the valuation of the costs of potential liquidity problems from the non-tradability of assets.

Valuation of risks and of costs of non-tradability necessarily involves an element of arbitrariness. They also depend on the strategy that is pursued, trading versus holding, perhaps also partial trading and holding, and on the interplay between the strategy that is pursued with the holder's funding costs and liquidity position.

Lack of information about the assets held and about the return prospects of these assets poses a challenge for any valuation. Whereas the information about the assets held should be available without too much ado, reliable information about their return prospects may be unattainable, so that assessments of these prospects involve a significant element of subjectivity.

At this point, professionals will refer to standard practices. Such practices have their uses, and professional routine may be one way of reducing subjectivity. However, in a situation where the overall exercise involves an important element of arbitrariness, one must ask whether the appeal to professional routine is sufficient to allay concerns about the quality of valuation in the context where it is used, here the context of bank resolution. 


\section{VALUATION IN RESOLUTION}

\subsection{The Resolution of Banco Popular Español}

Before discussing the challenges for valuation in resolution, I briefly review the resolution of BPE in June 2017. For 2016 already, the bank had announced substantial write-downs on real-estate loans. These write-downs more than wiped out the equity that had been raised in mid-2016. In early May 2017, the bank's report for the first quarter of 2017 showed further losses and strengthened concerns that the bank might actually be insolvent. The ensuing run on deposits accelerated towards the end of the month. Emergency liquidity assistance to the bank was approved on June 5, but then the bank was declared failing or likely to fail on June 6 and resolved on June 7.

The resolution of BPE involved a complete bail-in of all equity instruments (share capital, T1 and T2 instruments) and a sale of business to Banco Santander for $€ 1$. The resolution decision relied on an independent valuation that the Single Resolution Board (SRB) had ordered on May 23. The valuation report (Valuation 2) assessed the bank's equity as lying between $€ 1.3$ billion and $€-8.2$ billion, with a "best estimate" of $€-2.0$ billion. However, the report noted that the time span of 13 days had been too short to provide more than a provisional valuation. A final valuation (Valuation 3) has recently been prepared but is not yet public.

Not surprisingly, the investors who were bailed in are dissatisfied with the outcome, and some of them are going to court. The following matters may give rise to concern: First, the decision to declare the bank failing or likely to fail was justified by liquidity considerations, rather than solvency considerations. The assessment that, at the time of resolution, the bank had negative equity does not accord with that justification. Alternatively, if solvency concerns were present, why were they not raised earlier, say after the publication of results for the first quarter of 2017? Second, the admittedly short period for Valuation 2 may raise doubts about its reliability. The number for the best estimate for the bank's equity shortfall is eerily close to the total principal of the T1 and T2 instruments that were bailed in. The SRB focuses on the "conservative" assessment of an $€ 8.2$ billion shortfall, which the valuation report refers to as "worst case", in fact, the total principal of the T1 and T2 instruments that were bailed in is close to the "best estimate" of $a € 2$ billion shortfall. Third, the sale of the bank to Banco Santander has created a fait accompli, which does not leave much room for change in the valuation in the context of Valuation 3.

In considering this case, one must distinguish between procedural and substantive issues. Moreover, for the procedural issues, one must distinguish between problems under the given legislation and problems of the given legislation. As for the substantive issues, I am not convinced that the issues in this case are very serious, nor do I believe that they can be eliminated; I see the substantive issues as being closely related to the difficulties in the concept of valuation itself, which I discussed in the preceding section.

\subsection{The No-Investor-Worse-Off Principle}

From the perspective of investors, bank resolution is problematic because the resolution authority has the power to dispose of the bank's assets, wholly or partly, without their having a say. In contrast, under the insolvency laws of many countries, creditors have a say in an insolvency procedure. Moreover, the procedures themselves are usually carried out under the auspices of a court or a court-appointed receiver, with a possibility of legal recourse, which provides some protection.

In resolution under the BRRD or the SRM Regulation, the no-investor-worse-off principle is supposed to provide protection against any wilfulness of the resolution authority at the expense of investors. 
However, it is not quite clear what the principle actually means and how precisely it should be implemented in practice.

As I pointed out in the introduction, the payouts that investors get in an insolvency procedure are only found out ex post, when the proceeds from the disposal of the debtor's assets are known and distributed to the different investors. In contrast, the decisions of resolution authorities are taken ex ante, at a time when the proceeds from disposing of the debtor's assets are not yet known.

For the no-investor-worse-off principle, this discrepancy raises two issues. First, in a resolution procedure, one may never learn what investors' payouts in a counterfactual insolvency procedure would have been. Indeed the very resolution decision that is taken may preclude the attainment of such information by anybody. For example, when the sale-of-business tool is used, the bank and its assets are likely to be integrated into the purchaser's business so that no additional information about the assets, let alone the proceeds of a potential liquidation is generated. In this case, any assertion about the potential results of an insolvency procedure is counterfactual.

In this context, it is important to appreciate that forecasts of liquidation proceeds are often wildly optimistic. Moving from a going concern to a gone concern destroys value. Parties concerned are often unwilling to face reality and accept the need to take write-downs. Discourse about the matter is impeded by the fact that, as discussed in the above section on the assessment of asset return distributions, there usually are not enough data to permit statistically reliable estimates, in particular estimates of conditional distributions given the adverse developments that have taken place.

In cases where the bank in question poses a systemic risk, one must also consider whether the impact of non-resolution on the financial system should be taken into account in assessing the outcomes that would be obtained under the counterfactual of an insolvency procedure. In the case of Lehman Brothers, it seems clear that the losses to Lehman' creditors were much magnified by the turmoil in financial markets that the bankruptcy itself set off.

Second, should we think about the application of the no-investor-worse-off principle as applying ex post, after everything has been settled, or ex ante, at the time of the resolution decision. The legal norms are not clear about the matter. On the one hand, Valuation 3 is presented as an ex post valuation. The allowance for a buffer in a provisional Valuation 2 also suggests a final accounting ex post, when the realizations of risks are known, so that, if the buffer was not needed, a further distribution can made to investors. However, given that the correct information about the outcomes of a counterfactual insolvency is unlikely to be available at, the ex post adjustments that can be made with new information may be biased. It might therefore be more appropriate to formulate the assessment of what investors would have received in an insolvency procedure in ex ante terms, as of the time of the resolution decision.

The issue is implicit in some of the discussion about EBA's proposed RTS, in particular the discussions on whether Valuation 3 should take account of information that has become available in the interim between the resolution decision and the ex post valuation and in the discussion of how to think about the buffer in Valuation 2. Concerning the treatment of information that becomes available in the interim between the resolution decision and the ex post valuation, some respondents argue that this information should be used because it is relevant to the application of the no-investor-worse-off principle. Other respondents argue that this information should not be used because it has not been available at the time of the resolution decision. The conflict is easily understood once one appreciates that one side is thinking about the no-investor-worse-off principle as applying ex post, after everything has been settled, and the other side is thinking about applying it ex ante, at the time of the resolution decision. 
It would be desirable to have this issue clarified, either by a suitable change in the BRRD and the SRM Regulation or by a clarification through a delegated act of the Commission. Which way the clarification should go is of course up to the responsible bodies to decide. For reasons of practicality, I see some advantage in applying the no-investor-worse-off principle ex ante, i.e. at the time when the resolution authority is taking its decision.

If one were to go this route, however, one must deal with several issues that can arise. First, a bail-in decision taken at the time of the resolution procedure may leave the resolution authority with some residual risks. Second, as discussed in Section 2, applying the no-investor-worse-off principle ex ante requires an adjustment of the valuation of what investors would receive under an insolvency procedure by a risk premium to take account of the risk that investors face in an insolvency procedure.

A third issue concerns the treatment of the shareholders' default option. To understand the issue, consider the valuation of the equity of an ordinary corporation that is not in insolvency. Because of limited liability, the market value of the firm's shares can never be negative and must in fact always be greater than the difference between the market value of its assets and its nominal liabilities. Limited liability can be thought of as an arrangement that gives shareholders the option to default whenever the value of the corporation's assets is smaller than its liabilities, and the excess of the market value of equity over the difference between the market value of its assets and its nominal liabilities corresponds to the value of the default option. Because of the default option, it is quite possible that the market value of a firm's assets might be smaller than its liabilities and yet the market value of the firm's equity is positive. In this case, investors are "hoping for resurrection", anticipating that, with some probability, remaining risks (or new risks that the firm just takes on for this purpose) might turn out positive, taking the firm out of insolvency.

These considerations also apply to a firm's shares in an insolvency procedure. As long as the procedure is not over, there might be a small probability that some asset sales might turn out to be spectacularly successful, so that all creditors can be paid off, and something remains for shareholders. From an ex ante perspective, at the time of when the resolution procedure is initiated, this observation would imply that a complete write-down of shareholder equity would violate the no-investor-worse-off principle. Notice that this is true even if the company is insolvent in the sense that the value of its assets is less than its liabilities.

At this point, however, one must have doubts whether the no-investor-worse-off principle should be carried this far. In cases where a comparison of the value of assets and liabilities suggests that a bank is insolvent, a rule that, for shareholders, the no-investor-worse-off principle is satisfied if they are written down to zero, would seem reasonable. Extending this rule to T1 and T2 securities that have been converted into equity would also seem reasonable.

\subsection{Valuations 2 and 3 and the Sale-of-Business Tool}

In a sense, the concerns about the meaning of the no-investor-worse-off rule can be taken to be moot if the resolution authority uses the sale-of-business tool. If insolvency law allows for a sale of the business, the resolution action mimics what a receiver might have done, and the procedure is completed at once. One might therefore argue that the price obtained from the sale of the business corresponds to the proceeds that would be obtained in an insolvency procedure, so this price would provide the proper value for Valuation 3 ex post.

Affected parties are likely to object that the price in the sale of business was too low. This objection can always be made, but often it is not justified. Sellers often have exaggerated views of the value of an object to which they are attached, be it a house or a covered-bond subsidiary. With valuation, as with 
many other counterfactual assessments, the proof of the pudding is in the eating, i.e. in the move from the counterfactual assessment to the real transaction. ${ }^{11}$

In this context, however, there are reasons to believe that the price achieved by applying the sale-ofbusiness tool in resolution might actually be relatively high. First, if the acquirer has a business interest of his own that makes for a prospect of synergies, the price might reflect some of these synergies. ${ }^{12}$ Second, if the sale of business did not occur and the systemic risks attached to a failure of the bank in question come home, all asset prices are likely to be lower.

The main argument suggesting that a price is too low would point to a lack of competition among bidders. In the case of BPE, Banco Santander was the only bidder submitting a binding offer. Isn't this a proof that there was too little competition in the bidding? While such a conclusion cannot be ruled out, one must also keep in mind that the absence of alternative bidders may itself be indicative of lower valuations by the potential buyers and of their fear of a 'lemons' problem.

In the case of BPE, the private sales procedure that the bank itself had initiated in April 2017 had not proceeded very far. When the SRB stepped in and contacted the potential buyers who had been identified in the private procedure, only two of the addressees indicated sufficient interest to sign a nondisclosure agreement under which they gained access to BPE's data. Only one of these two banks submitted a binding offer. One cannot rule out the possibility that there was some form of cartelization but more likely the institutions that dropped out were afraid of the risks involved. If so, the lack of competition itself is indicative of the fact that a purchase of BPE was considered problematic. ${ }^{13}$

Even so, there is the procedural concern that, in contrast to insolvency procedures, investors did not have a say. As mentioned above, this concern is a key issue in bank resolution. A major challenge for for Valuations 2 and 3 and for the resolution authority is therefore to establish the legitimacy of the given valuation and decision.

This being said, one should not forget that shareholders usually do not have a say in an insolvency procedure. For hybrid securities that count as $\mathrm{T} 1$ or $\mathrm{T} 2$ equity, the argument is less clear, but it would not be unreasonable to think about them in the same terms as shareholders. After all, their contribution to the bank's loss absorption capacity is an essential part of their contract, for which they are compensated by a promise of higher payments as long as the bank stays out of trouble.

\subsection{Valuation 2, Economic Value and Hold Value}

In the preceding discussion, I have presumed that a sale of business was to take place and that, with a proper sales procedure, the agreed price in such a sale was an appropriate indicator of "value". This presumption is objectionable if one considers that a sale might not be the choice. If markets are

\footnotetext{
${ }^{11}$ In 2010/11, the German banks WestLB and Commerzbank made this experience when they tried to sell their covered-bond subsidiaries Westlmmo and Eurohypo in order comply with the conditions that the European Commission had set for its approval of state aid received in the financial crisis of 2008. At the prices they asked, they did not receive any offers, so they ended up winding the banks down rather than selling them.

${ }^{12}$ The point was extensively discussed in the context of Deutsche Bank's taking full control of Morgan Grenfell in 1989.

${ }^{13}$ One might still be concerned that the process was limited to Spanish banks. If so, this would seem like a violation of at least the spirit of the European Banking Union. However, given that they have even worse information, banks from other countries would probably be even more in fear of 'lemons' problems in such an acquisition than Spanish banks.
} 
depressed, a sale might only be possible at fire sale prices, with large discounts from what prices would be in normal times. Under such conditions, one might claim that the "economic value" of the bank is much higher and so would be the "value" of the bank if its assets were held forever, or at least until the markets come to their senses again and market prices become more "reasonable".

This reasoning is problematic and so is the concept of economic value. ${ }^{14}$ As a concept that differs from market value, it presumes that the person making the assessment is better able to assess "value" than the market. Given that, as discussed in Section 2, any statement about value is ultimately a statement about counterfactual transactions, the neglect of the constraint imposed by potential trading partners, i.e., the market, is problematic. When in 2010/11, WestLB asserted that its covered-bond subsidiary was worth at least $€ 500$ million, this was a statement about their views, but not a statement of fact. As a statement of fact, it was actually false, as shown by, first, the lack of buyers at this price and, second, the subsequent experience of Erste Abwicklungsanstalt, the asset management company that was created to wind down WestLB including Westlmmo.

A statement about "hold value" provides a measure of what a strategy of holding the business and winding it down over time might bring. As such, it informs the decision on whether it is more advisable to sell the business or to hold it. However, as I discussed in Section 2, a proper assessment of hold value must take account of risk and potential costs of illiquidity and subtract risk premia and illiquidity premia from discounted values of expected future returns.

In the case of BPE, risk premia do not seem to have been considered - unless they entered the discount rates that were used to go from return expectations to asset values. In this case, however, I do not see how return correlations were taken into account, correlations between the returns on assets in the bank's portfolio, in particular problem loans, as well as correlations between the returns on the overall asset portfolio and a relevant indicator of risk to the economy as a whole.

I have also seen no reference to funding and liquidity, which are relevant for a proper assessment of value from a strategy of holding an illiquid asset or business. Risk premia and illiquidity premia would be important for a valuation that is to provide a suitable basis for comparing sale and hold strategies. The order of magnitude involved is probably on a par with the order of magnitude involved in incomplete-information problems in the assessment. The fact that, for non-traded assets, risk premia and illiquidity premia are almost impossible to measure reliably should not be taken to imply that these costs are irrelevant. They are important and they should be taken into account in the resolution authority's choice of strategy. Doing so requires an exercise of judgment rather than measurement. The challenge is to exercise this judgment and have it inform the resolution decision without making the assessment and the choice that it informs appear arbitrary.

\subsection{The Need for More Time: Would a Moratorium on Withdrawals and Payouts be Useful?}

Expressions of unease about the resolution procedure for BPE focus on the time pressure under which the valuation and the resolution decision too place. The independent valuer himself emphasized that a thorough valuation would have required sic weeks rather than thirteen days, so the Valuation 2 report was explicitly referred to as provisional. The SRB's resolution decision also pointed to the urgency that was created by the depositors' run on BPE.

The question is to what extent the time pressure actually compromised the procedure and what might be done to deal with this kind of problem. In particular, could the problem be solved, or at least reduced, by a moratorium on withdrawals, as suggested by the European Commission?

\footnotetext{
${ }^{14}$ For an extensive discussion, see Hellwig (2017).
} 
The answer to the last question is simple: A moratorium on payouts is likely to exacerbate the difficulties. Invoking a moratorium is in itself an interference with creditors' rights, just like the initiation of a resolution procedure. An anticipation of a moratorium may merely accelerate the run. If depositors fear that a moratorium will shortly be imposed, this fear will already induce them to run, just like the fear of bail-in in a resolution procedure. With short-term wholesale funding, the creditors involved would not even have to run - it would be enough for them not to renew their lending. For this debt, a moratorium on payouts would amount to an outright default.

More importantly, with a systemically important institution, a moratorium on payouts can cause severe damage to the overall financial system and the real economy. Firms and other institutions with large, hence uninsured deposits, which rely on these deposits for their payments and their cash management, may find that their day-to-day activities are severely damaged by a moratorium, for example their ability to pay their workers and their suppliers. The consequences for the real economy can be highly disruptive. Attempts of these institutions to somehow get cash for payments can induce them to make large withdrawals from other banks where they have accounts, thus putting pressure on these other banks. Contagion effects of this sort were very much in evidence and were very destructive in early 1933 in the United States when individual states tried to stem runs on "their" banks by moratoria on payouts ("bank holidays") in their territories. Firms responded by withdrawing cash from their accounts at banks in other states in order to pay their workers and their suppliers. There was thus a chain-reaction of runs and moratoria, in one state after the other, culminating in the nationwide "bank holiday" (and bank closures) of early March 1933. ${ }^{15}$

As for the effects of providing more time for the valuation, such time might improve the information about return prospects that can be gathered from the data provided by the bank. It cannot however remove the arbitrariness involved in the valuation of risk and uncertainty attached to non-tradable assets.

The time that is available for valuation could of course be extended if the demand for a valuation report was issued earlier, provided confidentiality was preserved. In the case of BPE, it is somewhat irritating, that the SRB waited until May 23 to demand a valuation report. The series of bad news that culminated in the announcement of early May 2017 should have rung the alarm. If depositors suspect an insolvency, so surely might the SRB, at least to the extent of asking for a report that would not commit it to anything.

This being said, I find it disconcerting that on May 23, 2017, and May 31, 2017, the media contained reports about the SRB and BPE that seemed to rely on indiscretions. As an outsider I cannot judge the background to these reports, but I find it eerie that the date of the first report is the date when the SRB asked for the independent Valuation 2 report and that the information contained in the second report was close to what was about to happen. If the processes are accompanied by indiscretion, no amount of timeliness of the authority's intervention can get ahead of the depositors' run.

\subsection{The Need for More Time: The Problem of Funding}

More fundamentally, the run problem is only a symptom of a deeper problem. Resolution itself takes time. During this time, whoever holds and manages the bank's assets need funding. The BRRD and the SRM Regulation do not provide for arrangements that would secure this funding.

\footnotetext{
${ }^{15}$ See Friedman and Schwartz (1963)
} 
In the case of BPE, the problem of time and funding appears only as a problem concerning the time needed for a through Valuation 2. However, the problem also concerns any strategy of holding the bank's assets in order to avoid selling them at fire sale prices. The problem was in evidence in the Italian decision not to liquidate Banca Popolare di Vicenza and Veneto Banca under insolvency law, with a fast liquidation at presumably low prices, and instead to place the problem loans of these two banks into a "bad bank", with funding from Intesa Sanpaolo, with a government guarantee against losses. With assured funding, the illiquidity premium in the hold value may be taken to be zero, so there is plenty of time to wind the loans down without any recourse to the market.

Without an assurance of sufficient funding, any reference to a strategy of holding and managing assets and any reference to the associated hold value is purely academic. If the funding is not available, such a strategy is not feasible. As a result, any assessment that the hold value of the bank is higher than the price that is offered by a potential acquirer is moot because the hold strategy may simply not be feasible.

On the other hand, if funding is available, the run problem is harmless. With assured funding, the resolution authority can take control of the bank and then decide which strategy to pursue. In the process, there would also be plenty of time for a more thorough valuation.

A change in the legal framework that would address the problem of funding in resolution would thus be a highly desirable improvement. If this problem were addressed, in fact, most of the issues raised in this paper would become moot or easily solvable.

An example is provided by the Federal Insurance Corporation (FDIC) in the United States. The FDIC finances its operations by an industry levy and by clawbacks (bail-in) from creditors. From past dues on the levy it has a fund of its own that it can use. The amount in this fund is usually small, but the FDIC also can obtain interim funding by borrowing from the US Treasury. The arrangement enables the FDIC to take control of failing banks and then to dispose of them without worrying about funding, quickly or slowly, depending on which alternative seems more promising. In the case of the savings and loans crisis, it took some ten years to wind the operation down, but the patience paid off. Total losses ended up at $\$ 153$ billion, rather than the $\$ 600-800$ billion that had been speculated about in the early 1990 s. 


\section{CONCLUSIONS}

The greatest challenge for valuation in resolution and for the resolution procedure itself is to establish credibility and legitimacy. The main difficulty is that "value" is not something objectively given that one can easily measure. "Value" refers to a counterfactual, an exchange of an object for money that does not actually take place. The counterfactual nature of the concept creates no difficulties if equivalent objects, e.g. assets with the same return patterns, actually are traded in markets. But even then one must be cautious about the possibility that the expression of a desire to trade may affect market prices, because markets are illiquid, because of market power, or because potential buyers are afraid of 'lemons' effects stemming from information asymmetries.

For assets are not traded in markets, it is unlikely that traded assets are fully equivalent. In particular, such assets are unlikely to exhibit the same risk characteristics. The treatment of risk in the returns of a non-traded asset may therefore involve a certain element of arbitrariness. The same is true for the treatment of illiquidity costs, i.e. the costs that the holder of a non-tradable asset may incur because in a liquidity crunch the asset cannot be sold, or not be sold without a loss.

The assessment of probability distributions of future returns may also involve important elements of subjective judgment. This is especially true for loans, where randomness is associated with default, which is a rare event. With lending for the purchase of durable assets like real estate or ships, the additional problem arises that default probabilities depend on the market situation, more concretely, on whether the markets for the durable are in a boom phase or a bust phase.

In the application of the BRRD and the SRM Regulation, a major problem comes from the fact that the no-investor-worse-off principle is unclear. On the face of it, the standard of comparison for this principle is given by the ex post outcome under an insolvency procedure. This standard however is unrealistic because the ex post outcome under an insolvency procedure often cannot be known. This outcome depends on the resolution of uncertainty in the insolvency procedure itself. Information about how uncertainty would be resolved in an insolvency procedure is often unattainable because resolution itself pre-empts the insolvency procedure. It may therefore be more practical to think about the noinvestor-worse-off principle from an ex ante perspective, at the time when the resolution decision is taken. At this time, the returns to investors from an insolvency procedure are not known, but one can form expectations about their probability distributions and assess their values. The value assessment involves elements of subjective judgment about risk premia, but this may be less problematic than the biases that arise in a counterfactual ex post assessment when some aspects of the counterfactual resolution of uncertainty in an insolvency procedure can be assessed and others, perhaps more important, cannot.

When the sale-of-business tool is applied, there are reasons to believe that the sales price itself provides a good reference for Valuation 3, at least if the bidding process was sufficiently competitive. If the bidding process was competitive, the sales price is likely to higher than what would be received in an insolvency procedure. An assessment of competitiveness of the bidding process should not focus on the number of bids received but on the openness of the process to potential bidders. The number of bids received may reflect the potential bidders' assessments of the business and their own ability to address the problems that forced the institution into resolution.

The concept of "economic value", as distinct from market value, is problematic if there is no feasible strategy attached to it. If markets are depressed, one may consider prices to be abnormally low, so that holding and managing them is preferred to a sale. That is a legitimate business judgment provided the strategy of holding and managing them is actually feasible. In this case, however, an assessment of 
hold value ought to take account of risk premia, because the returns on the assets are not known in advance, and of illiquidity premia, because the lack of tradability can impose additional costs on the holder. For non-tradable assets, the assessment of risk premia and illiquidity premia involves important elements of subjectivity because by the very non-tradability, market information for the assessment is not available, at least not complete.

If a strategy of holding and managing the asset is considered, one needs funding. The BRRD and the SRM Regulation are silent on the subject of funding in resolution. The lack of provisions for funding in resolution is a major reason why time pressure is so strong in the European Union, in contrast to the United States, where the FDIC can obtain interim funding by borrowing from the Treasury. It would be desirable to amend the legislation to provide for funding in resolution. This would reduce the time pressure and make holding and managing assets a viable alternative to shotgun measure over the proverbial resolution weekend, or in the case of BPE resolution night.

In the case of BPE, due to the run on the bank, time pressure also affected the valuation by external valuers (Valuation 2). This problem would also be reduced if there were provisions for funding in resolution. The proposal to allow for a moratorium on payouts would not really solve the problem; it might just shift it forward as investors begin to run for fear of a moratorium where before they ran for fear of resolution. A moratorium might however have disastrous side effects.

The authorities should think about the desirability of initiating the valuation process sooner, while ensuring that there are no indiscretions that might themselves trigger a run.

Providing the valuation with more time may improve the information that is available, but it cannot eliminate the elements of subjectivity and arbitrariness inherent in the valuation of risks and of illiquidity of non-tradable assets. It also cannot eliminate the elements of subjectivity in the assessment of conditional probability distributions of future returns where reliable data are altogether missing. 


\section{REFERENCES}

Admati, A.R., P.M. DeMarzo, M.F. Hellwig, and P.C. Pfleiderer (2018). The Leverage Ratchet Effect. Journal of Finance 73, $145-198$.

Akerlof, G. A. (1970). The Market for 'Lemons'. Quarterly Journal of Economics 84, 488 - 500.

Arrow, K.J. (1954/1963). Le rôle des valeurs boursières pour la répartition la meilleure des risques, Économétrie, Colloques Internationaux du Centre National de la Recherche Scientifique 11 (1953), 41 - 47. English translation: The Role of Securities in the Optimal Allocation of Risk Bearing. Review of Economic Studies 31 (1964), 91 -96.

Behn, M., R. Haselmann, and V. Vig (2016). The Limits of Model-Based Regulation. Working Paper No. 1928, European Central Bank Working Paper Series, European Central Bank, Frankfurt.

Black, F., and M.S. Scholes (1973). The Pricing of Options and Corporate Liabilities. Journal of Political Economy 81, $637-654$.

Debreu, G. (1959). Theory of Value: An Axiomatic Analysis of Economic Equilibrium. Cowles Foundation Monograph 17, Yale University Press, New Haven, 1959.

EBA (2017). Final Draft on Valuation before Resolution, Final Draft on Valuation after Resolution. EBA/RTS/2017/05 and EBA/RTS/2017/06, European Banking Authority, London.

Friedman, M., and A.J. Schwartz (1963). A Monetary History of the United States 1867 - 1960. Princeton University Press, Princeton, N.J.

Harrison, J.M., and D.M. Kreps (1979). Martingales and Arbitrage in Multiperiod Security Markets. Journal of Economic Theory 20, $381-408$.

Hellwig, M.F. (2013). Stellungnahme zur Anhörung des Haushaltsausschusses der Bürgerschaft der Freien und Hansestadt Hamburg über die Wiedererhöhung der Ländergarantie für HSH Nordbank. Hamburg, 30 April 2013.

Hellwig, M.F. (2017). Carving out Legacy Assets: A Successful Tool for Successful Restructuring? European Parliament, Economic and Monetary Affairs Committee, Brussels.

Hellwig, M.F. (2018), Germany and the Financial Crises 2007 - 2017. Paper presented the Annual Macroprudential Conference. Sveriges Riksbank, Stockholm.

Lintner, J.V. (1965). The Valuation of Risk Assets and the Selection of Risky Investments in Stock Portfolios and Capital Budgets. Review of Economics and Statistics 47, 13-37. 
IPOL | Economic Governance Support Unit

Merton, R.C. (1973a). Theory of Rational Option Pricing. Bell Journal of Economics and Management Science 4, $141-183$.

Merton, R.C. (1973b). An Intertemporal Capital Asset Pricing Model. Econometrica 41, 867 - 887.

Merton, R.C. (1974). On the Pricing of Corporate Debt: The Risk Structure of Interest Rates. Journal of Finance 29, $449-470$.

Ross, S.A. (1976). Options and Efficiency. Quarterly Journal of Economics 90, 75 - 89.

Sharpe, W.F. (1964). Capital Asset Prices: A Theory of Market Equilibrium under Conditions of Risk. Journal of Finance 19, 425-442. 


This document was provided by the Economic Governance Support Unit at the request of the ECON Committee.

\section{DISCLAIMER}

The opinions expressed in this document are the sole responsibility of the author and do not necessarily represent the official position of the European Parliament.

Reproduction and translation for non-commercial purposes are authorised, provided the source is acknowledged and the publisher is given prior notice and sent a copy.

PE 624.417

Print ISBN 978-92-846-3219-0 | doi:10.2861/963433 | QA-09-18-009-EN-C

PDF ISBN 978-92-846-3217-6 | doi:10.2861/46486| QA-09-18-009-EN -N 